\title{
Pengaruh Iklim terhadap Kasus Demam Berdarah Dengue
}

\author{
Margareta Maria Sintorini*
}

\begin{abstract}
Abstrak
Penyakit demam berdarah dengue (DBD) telah menjadi penyakit endemik di kota-kota besar di Indonesia. Ramalan Intergovernmental Panel on Climate Change tahun 1996 menyebutkan insidens DBD di Indonesia dapat meningkat tiga kali lipat pada tahun 2070. Tujuan penelitian ini untuk membuat model dinamika sistem dengan analisis ekologi untuk mengetahui dinamika kejadian DBD dalam kaitan dengan pola variablitas iklim di DKI Jakarta. Rancangan penelitian digunakan adalah ecologic study dengan uji hipotesis, permodelan, simulasi, dan intervensi. Wawancara terhadap 844 responden untuk mengetahui tingkat pengetahuan, sikap, dan perilaku (PSP) masyarakat. Pengukuran faktor iklim meliputi curah hujan, suhu, kelembaban, intensitas cahaya, dan kadar $\mathrm{CO}_{2}$. Aspek vektor yang diukur adalah angka hinggap per jam nyamuk Aedes (AHJ) dan nyamuk istirahat per rumah (NIR). Hasil penelitian menunjukkan kasus DBD dipengaruhi curah hujan (p:0,000..), suhu lingkungan ( $p: 0,000$..), kelembaban ruang ( $\mathrm{p}: 0,003)$, kelembaban lingkungan ( $\mathrm{p}: 0,000 .$.$) , AHJ$ Aedes (p:0,016), NIR Aedes (p:0,000..) dan pengetahuan masyarakat (p:0,008). Disimpulkan, faktor iklim yang paling berpengaruh terhadap kasus DBD adalah curah hujan, suhu dan kelembaban serta pengetahuan masyarakat yang rendah. Sedangkan AHJ Aedes dapat dijadikan indikator kenaikan kasus DBD.
\end{abstract}

Kata kunci: Demam berdarah dengue, perubahan iklim

\section{Abstract}

Dengue hemorrhagic fever (DHF) has become endemic in many big cities in Indonesia. It was predicted by Intergovernmental Panel on Climate Change, that in 1996 the DHF in Indonesia in 2070 would be tripled. The objective of this research is to make a system dynamic model using ecological analysis to identify the dynamic of DHF cases related to the pattern of the climate variability in Jakarta. This research uses the design of ecological study with hypothesis testing, modelling, simulation, and intervention. Respondents of 844 households were interviewed to explore their knowledge, attitude and practice (KAP) regarding DHF using a standard questionnaire. Precipitation, humidity, light intensity and $\mathrm{CO}_{2}$ concentration were determined per week. AHJ (Man Landing Rate) and NIR (resting habit) were determined for Aedes population density. The results indicate that the DHF cases all are influenced by precipitation ( 0.000$)$, temperature ambient $(0.000)$, indoor humidity $(0.003)$, outdoor humidity $(0.000)$, AHJ $(0.016)$, NIR $(0.000)$, and knowledge $(0.008)$. The most influencial climate factor to the DHF cases are precipitation, temperature, humidity and the low level of the community knowledge.

Key words: Dengue hemorrhagic fever, climate change 
Proyeksi kecenderungan aktivitas ekonomi dan dampak emisi gas kegiatan manusia, pada tahun mendatang, tempaknya berpengaruh tehadap pergeseran pola curah hujan dan suhu rata-rata bumi yang diperkirakan naik $1-3,5^{\circ} \mathrm{C}$. Perubahan pada komponen lingkungan ini akan mempengaruhi spesies-spesies pada kelompok ekosistem dan pola penyebaran vektor serta virus penyakit. ${ }^{1}$ Iklim dapat berpengaruh terhadap pola penyakit infeksi karena agen penyakit (virus, bakteri, atau parasit lainnya) dan vektor (serangga atau rodensia) bersifat sensitif terhadap suhu, kelembaban dan kondisi lingkungan ambien lainnya. Cuaca dan iklim berpengaruh terhadap penyakit yang berbeda dengan cara yang berbeda. ${ }^{2}$ Penyakit yang ditularkan melalui nyamuk seperti demam berdarah dengue (DBD), malaria dan demam kuning berhubungan dengan kondisi cuaca yang hangat. Sebaliknya, influensa berhubungan dengan kondisi cuaca yang dingin dan meningitis berhubungan dengan kondisi lingkungan yang kering. ${ }^{3}$ Banyak yang menduga bahwa KLB DBD yang terjadi setiap tahun hampir seluruh di
Indonesia terkait erat dengan pola cuaca di Asia Tenggara. Tingkat penyebaran virus diperkirakan mengalami peningkatan pada peralihan musim yang ditandai oleh curah hujan dan suhu udara yang tinggi. ${ }^{4}$ Selain itu, perubahan gaya hidup ikut berperan menambah population at risk. Penggunaan barang non biodegradable seperti plastik yang sangat tinggi, menyebabkan plastik menjadi komposisi sampah terbesar saat ini sehingga berpotensi menjadi penampung air hujan, tempat perkembangbiakan vektor. ${ }^{5}$

\section{Metode}

Penelitian dengan sumber data primer yang dikumpulkan pada bulan April 2004 sampai Maret 2005 dan sekunder ini menggunakan disain studi ekologi, dengan uji hipotesis. ${ }^{6-8}$ Data dikumpulkan dari lima wilayah kotamadya DKI Jakarta yang ditetapkan sebagai kecamatan rawan DBD oleh Pemda DKI. Daerah tersebut meliputi Kecamatan Pasar Minggu Jakarta Selatan, Kecamatan Ciracas Jakarta Timur, Kecamatan Tanjung Priok Jakarta
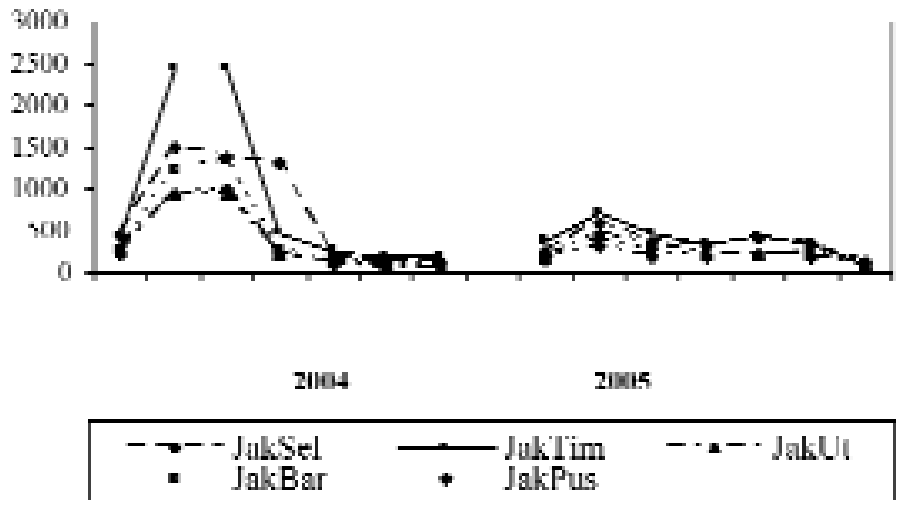

Tabel 1. AHJ Aedes di DKI Jakarta, April 2004-Maret 2005

\begin{tabular}{lcccccc}
\hline Bulan & $\begin{array}{c}\text { Jakarta } \\
\text { Selatan }\end{array}$ & $\begin{array}{c}\text { Jakarta } \\
\text { Timur }\end{array}$ & $\begin{array}{c}\text { Jakarta } \\
\text { Utara }\end{array}$ & $\begin{array}{c}\text { Jakarta } \\
\text { Barat }\end{array}$ & $\begin{array}{c}\text { Jakarta } \\
\text { Pusat }\end{array}$ & Rata-rata \\
\hline April & 1,57 & 1,10 & 1,90 & 1,00 & 1,70 & 1,45 \\
Mei & 1,00 & 1,21 & 1,73 & 0,83 & 1,50 & 1,25 \\
Juni & 1,20 & 0,72 & 1,56 & 1,56 & 0,90 & 1,19 \\
Juli & 1,67 & 0,65 & 1,00 & 1,85 & 0,50 & 1,13 \\
Agustus & 2,17 & 1,13 & 0,73 & 1,53 & 0,80 & 1,27 \\
September & 2,75 & 1,30 & 1,32 & 1,57 & 1,60 & 1,71 \\
Oktober & 1,80 & 0,86 & 1,00 & 1,21 & 1,40 & 1,25 \\
November & 0,60 & 1,20 & 0,71 & 0,55 & 1,25 & 0,86 \\
Desember & 0,72 & 1,81 & 0,50 & 1,14 & 1,90 & 1,21 \\
Januari & 1,56 & 2,17 & 1,37 & 1,64 & 2,33 & 1,81 \\
Februari & 2,21 & 2,53 & 2,11 & 1,87 & 2,73 & 2,29 \\
Maret & 1,73 & 2,40 & 1,98 & 1,20 & 2,50 & 1,96 \\
\hline Rata-rata & $\mathbf{1 , 5 6}$ & $\mathbf{1 , 4 2}$ & $\mathbf{1 , 3 3}$ & $\mathbf{1 , 3 3}$ & $\mathbf{1 , 5 9}$ & $\mathbf{1 , 4 5}$ \\
\hline
\end{tabular}


Tabel 2. Distribusi Frekuensi Responden yang Pernah Menderita DBD dalam Dua Tahun Terakhir

\begin{tabular}{lccccc}
\hline Lokasi & \multicolumn{2}{c}{ Ya } & \multicolumn{4}{c}{ Tidak } & Jumlah \\
penelitian & Jumlah & $\%$ & Jumlah & $\%$ & \\
\cline { 2 - 5 } & & & & & \\
Jakarta Selatan & 13 & 7,3 & 165 & 92,7 & 173 \\
Jakarta Timur & 19 & 11,6 & 145 & 88,4 & 164 \\
Jakarta Utara & 12 & 7,5 & 147 & 92,5 & 159 \\
Jakarta Barat & 7 & 4,1 & 163 & 95,9 & 170 \\
Jakarta Pusat & 16 & 9,2 & 157 & 90,8 & 173 \\
Jumlah & $\mathbf{6 7}$ & $\mathbf{7 , 9 4}$ & $\mathbf{7 7 7}$ & $\mathbf{9 2 , 0 6}$ & $\mathbf{8 4 4}$ \\
\hline
\end{tabular}

Utara, Kecamatan Palmerah Jakarta Barat, dan Kecamatan Tanah Abang Jakarta Pusat. Selanjutnya, dilakukan permodelan serta simulasi untuk mengidentifikasi pengaruh faktor cuaca terhadap kasus DBD. Variabel yang diamati pada penelitian ini meliputi curah hujan, peluang kontak nyamuk yang diidentifikasi melalui penghitungan Angka Hinggap Nyamuk per Jam (AHJ), ${ }^{7}$ dan kasus DBD di masyarakat baik yang dikumpulkan sebagai data primer melalui wawancara maupun data sekunder yang dikumpulkan oleh Dinas Kesehatan.

\section{Hasil}

\section{Fluktuasi kasus DBD}

Grafik kasus DBD diseluruh wilayah DKI Jakarta pada tahun 2004 dan 2005 memperlihatkan tiga ciri berikut: (a) Kasus DBD tahun 2004 dan 2005 mencapai puncak pada sekitar bulan Februari-Maret (Gambar 1). Data kasus DBD per wilayah dari bulan Januari 2004 hingga Juli 2005 menunjukkan bahwa peningkatan kasus DBD mulai sekitar Januari hingga mencapai puncaknya pada bulan MaretFebruari adan pada bulan April terlihat masih tinggi tetapi sudah mulai menurun dan mencapai tirik terendah pada bulan September-November dan pada bulan Januari kembali beranjak naik. (b) Kasus DBD di seluruh wilayah DKI pada tahun 2004 lebih tinggi dari 2005, tetapi kasus pada bulan Mei dan Juni tahun 2005 lebih tinggi dibandingkan pada tahun 2004. (c) Pola urutan grafik kasus DBD sepanjang tahun adalah konstan. Kasus DBD tertinggi sepanjang tahun 2004 dan 2005 terjadi di Jakarta Timur, kemudian secara berurutan diikuti Jakarta Selatan, Jakarta Barat dan kasus terendah ada di Jakarta Pusat. (Lihat Gambar 1)

\section{Gambaran Vektor dan Kasus DBD}

Jumlah nyamuk dewasa yang hinggap per orang per jam $(\mathrm{AHJ})$ adalah 1,45 dengan penyimpangan sebesar 1,45 \pm 0,63 . AHJ terendah $(0,55)$ ditemukan pada bulan November di Jakarta Barat dan yang tertinggi adalah 2,75 pada bulan September di Jakarta Selatan. Secara keseluruhan rata-rata AHJ Jakarta Barat rendah, maksimum terjadi pada bulan Juli-September dan Februari. Korelasi positif yang sangat lemah terjadi pada bulan Juli, September dan Februari. Hal tersebut berbeda dengan Jakarta Pusat. Pada periode April-Juli, AHJ memperlihatkan kecenderungan yang menurun secara pelahan dan mencapai puncak yang pertama pada bulan September. pada saat itu ,kurva curah hujan memperlihatkan kecenderungan yang menurun. Grafik Angka Hinggap bulan November-Maret menyerupai grafik di Jakarta Barat (Lihat Tabel 1).

Dari 844 responden yang diamati, diketahui gambaran kasus DBD di DKI Jakarta, meliputi 67 orang $(7,94 \%)$ pernah menderita DBD pada dua tahun terakhir dan 777 responden $(92,06 \%)$ tidak menderita DBD (Lihat Tabel 2).

Kasus DBD di setiap wilayah di DKI Jakarta pada sepanjang tahun 2004 terlihat lebih tinggi daripada tahun 2005 (Tabel 3 ; Gambar 1).

\section{Gambaran Curah Hujan}

Gambaran curah hujan per bulan terlihat pada Tabel 4 , curah hujan tertinggi rata-rata per bulan yang terukur selama pengamatan ditemukan pada bulan Januari dan

Tabel 3. Jumlah Kasus DBD di DKI Jakarta, Tahun 2004-2005

\begin{tabular}{|c|c|c|c|c|c|c|c|c|c|c|}
\hline \multirow[t]{2}{*}{ Bulan } & \multicolumn{2}{|c|}{ Jakarta Selatan } & \multicolumn{2}{|c|}{ Jakarta Timur } & \multicolumn{2}{|c|}{ Jakarta Utara } & \multicolumn{2}{|c|}{ Jakarta Barat } & \multicolumn{2}{|c|}{ Jakarta Pusat } \\
\hline & 2004 & 2005 & 2004 & 2005 & 2004 & 2005 & 2004 & 2005 & 2004 & 2005 \\
\hline Jan & 452 & 265 & 473 & 376 & 282 & 192 & 245 & 188 & 209 & 151 \\
\hline Feb & 1486 & 593 & 2435 & 713 & 939 & 465 & 1265 & 398 & 947 & 315 \\
\hline Maret & 1364 & 389 & 2432 & 461 & 936 & 330 & 1333 & 250 & 987 & 195 \\
\hline April & 297 & 306 & 475 & 331 & 227 & 219 & 271 & 187 & 208 & 193 \\
\hline Mei & 141 & 407 & 249 & 439 & 117 & 214 & 112 & 199 & 83 & 212 \\
\hline Juni & 122 & 340 & 191 & 339 & 83 & 217 & 106 & 248 & 71 & 203 \\
\hline Juli & 112 & 123 & 180 & 106 & 67 & 96 & 87 & 81 & 54 & 54 \\
\hline Agust & 73 & & 134 & & 66 & & 49 & & 46 & \\
\hline Sept & 54 & & 95 & & 42 & & 44 & & 46 & \\
\hline Okt & 62 & & 115 & & 40 & & 46 & & 42 & \\
\hline Nov & 44 & & 96 & & 47 & & 44 & & 25 & \\
\hline Des & 93 & & 152 & & 59 & & 73 & & 51 & \\
\hline Jumlah & 4300 & 2423 & 6991 & 2765 & 2905 & 1733 & 3675 & 1551 & 2769 & 1323 \\
\hline
\end{tabular}


Tabel 4. Curah Hujan (mm) Rata-rata per Bulan di DKI Jakarta, April 2004-Maret 2005

\begin{tabular}{lcccccc}
\hline Bulan & $\begin{array}{c}\text { Jakarta } \\
\text { Selatan }\end{array}$ & $\begin{array}{c}\text { Jakarta } \\
\text { Timur }\end{array}$ & $\begin{array}{c}\text { Jakarta } \\
\text { Utara }\end{array}$ & $\begin{array}{c}\text { Jakarta } \\
\text { Barat }\end{array}$ & $\begin{array}{c}\text { Jakarta } \\
\text { Pusat }\end{array}$ & Rata-rata \\
\hline April & 8,78 & 12,65 & 5,52 & 6,02 & 5,36 & 7,67 \\
Mei & 1,85 & 2,27 & 1,86 & 4,38 & 4,21 & 2,91 \\
Juni & 3,35 & 3,21 & 2,73 & 3,89 & 2,75 & 3,19 \\
Juli & 1,07 & 2,68 & 0,78 & 1,54 & 2,12 & 1,64 \\
Agustus & 1,95 & 2,03 & 1,39 & 2,31 & 2,45 & 2,03 \\
September & 0,51 & 1,65 & 0,43 & 2,8 & 2,52 & 1,58 \\
Oktober & 1,08 & 2,17 & 0,97 & 0,86 & 2,25 & 1,47 \\
November & 0,78 & 0,67 & 2,14 & 2,93 & 3,23 & 1,95 \\
Desember & $\mathbf{3 , 4 0}$ & 2,95 & 3,78 & 4,21 & 4,55 & 3,78 \\
Januari & 18,57 & $\mathbf{2 2 , 7 3}$ & 10,54 & 23,27 & 19,74 & 18,97 \\
Februari & 18,83 & $\mathbf{2 0 , 1 5}$ & 12,65 & 18,35 & 15,55 & 17,11 \\
Maret & 10,25 & 14,33 & 8,37 & 14,78 & 12,73 & 12,10 \\
\hline Rata-rata & $\mathbf{5 , 8 7}$ & $\mathbf{7 , 2 9}$ & $\mathbf{4 , 2 6}$ & $\mathbf{7 , 1 1}$ & $\mathbf{6 , 4 6}$ & $\mathbf{6 , 2 0}$ \\
\hline
\end{tabular}

Gambar 2 Hubungan Kasus DBD, Curah Hujan dan AHJ per bulan di DKI Jakarta, April 2004-Maret 2005

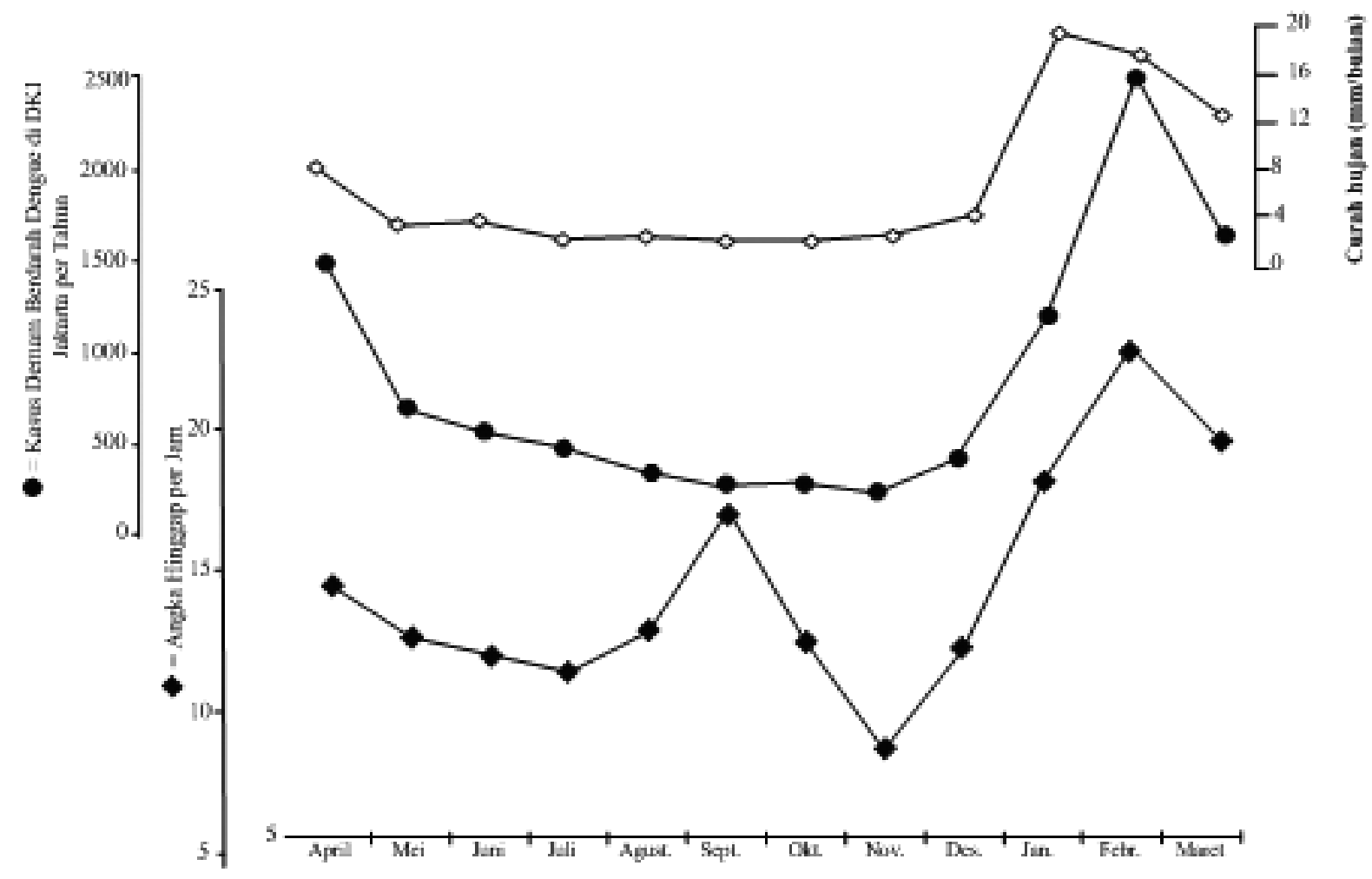

Februari 2005, curah hujan terendah pada bulan Oktober dan November 2004.

Gambaran curah hujan, gambaran kasus DBD serta $\mathrm{AHJ}$ per bulan ditunjukkan dalam bentuk grafik yang terdapat pada Gambar 2. Analisis bivariat memperlihatkan bahwa curah hujan mempengaruhi AHJ secara bermakna (p:0,000), sedangkan jumlah kasus DBD secara statistik multivariat dipengaruhi $\mathrm{AHJ}(\mathrm{p}: 0,000)$ dan curah hujan secara bermakna (p:0,002). Penghitungan koefisien determinasi mendapatkan angka 0,286 yang menunjukkan hanya $28,6 \%$ proporsi variasi $\mathrm{AHJ}$ dapat dijelaskan oleh curah hujan dan sekitar 71,4\% dapat diterangkan oleh faktor lain.

Prediksi Kasus DBD Berdasarkan Simulasi Model

Sistem dinamik yang dibangun memperlihatkan em- 
Gambar 3 Causal Loop Diagram (CLD) Model Dasar Kejadian Penyakit DBD di DKI Jakarta

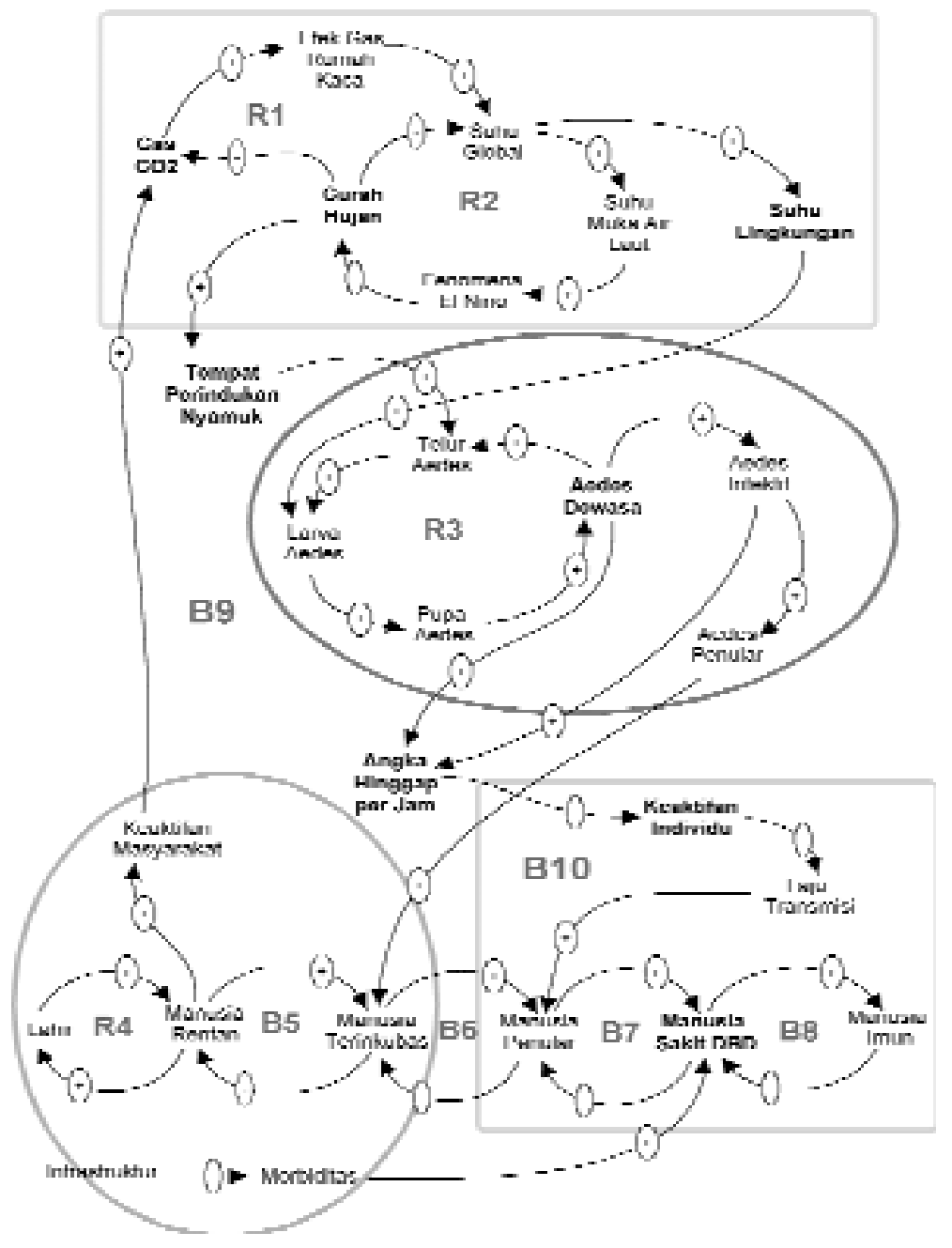

Gambar 4 Hasil Simulasi Model Dasar Kejadian Penyakit DBD

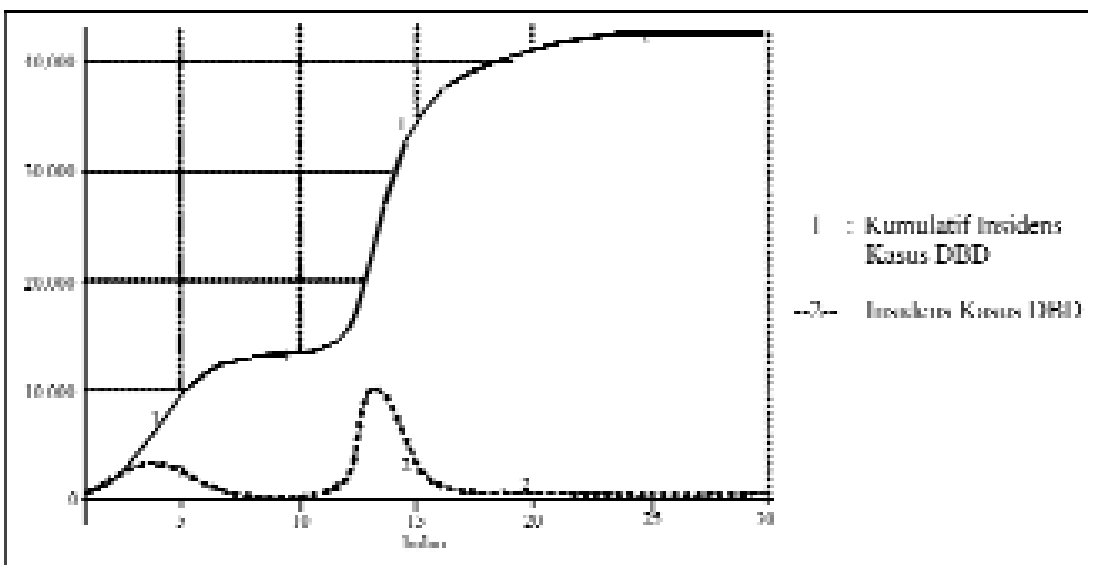


pat subsistem yang berhubungan dengan proses kejadian penyakit DBD. Hal tersebut meliputi subsistem iklim, subsistem nyamuk Aedes, subsistem manusia, dan subsistem penyakit DBD (Gambar 3). Keempat subsistem ini saling mempengaruhi.

Hasil simulasi Gambar 3 selama dua tahun (20032004) pada model dasar atau model referensi menunjukkan grafik insidens DBD (garis terputus) yang berfluktuasi Lonjakan kasus terjadi saat outbreak pada tahun 2004, sedangkan angka kumulatif kasus DBD selama dua tahun tersebut terlihat cenderung meningkat seperti terlihat pada Gambar 4.

\section{Pembahasan}

Dalam penelitian ini keaktivan nyamuk yang dinyatakan sebagai $\mathrm{AHJ}$ menjadi media antara subsistem vektor dan subsistem penyakit DBD (Gambar 3). Timbulnya gejala penyakit DBD dimulai dari saat kontak nyamuk dengan manusia. ${ }^{8}$ Hubungan bermakna dari hasil uji statistik dinyatakan dengan nilai kebermaknaan $(p)<0,05$. Nilai p AHJ Aedes dengan curah hujan dan kasus DBD mendekati angka 0,000. Pada tabel tersebut juga diketahui bahwa terdapat hubungan bermakna antara jumlah kasus DBD dengan curah hujan (p:0,000) dan AHJ (p:0,002), sedangkan AHJ berhubungan bermakna dengan curah hujan yang terjadi (p:0,000).

Pada Gambar 3 secara umum menunjukkan ketika curah hujan tinggi AHJ Aedes juga meningkat, seperti yang terjadi pada bulan Desember. Namun, bulan September saat curah hujan rendah AHJ justru terlihat meningkat. Hal ini disebabkan oleh faktor lain selain curah hujan, yaitu suhu dan kelembaban lingkungan. Faktor ini yang secara langsung mempengaruhi metabolisme nyamuk vektor ${ }^{8}$ dan diduga juga mempengaruhi virulensi virus dengue ${ }^{9}$ yang menyebabkan kasus tetap rendah. Mulai bulan Desember AHJ meningkat, demikian pula jumlah kasus cenderung meningkat dan mencapai puncaknya pada bulan Februari.

Berdasarkan hasil analisis statistik diketahui terdapat hubungan bermakna antara jumlah kasus DBD dengan curah hujan (p: 0,000) dan AHJ (p:0,002). Sedangkan hasil analisis uji statistik hubungan antara $\mathrm{AHJ}$ dan curah hujan (p: 0,000) memperlihatkan hubungan yang secara statistik bermakna antara AHJ dengan curah hujan. Ketika musim hujan datang maka ketersediaan TPN meningkat. Seperti diketahui bahwa Aedes lebih menyukai air bersih untuk meletakkan telurnya. Seekor nyamuk Aedes akan bertelur bekisar antara 100-300 butir, sehingga populasi nyamuk meningkat dengan cepat. ${ }^{8}$ Untuk mematangkan telurnya maka nyamuk akan mencari mangsa manusia, sehingga kecenderungan untuk menggigit manusia bertambah. Hal inilah yang menyebabkan AHJ ikut meningkat saat curah hujan tinggi.

Yang menjadi masalah adalah ketika nyamuk Aedes membawa virus dengue, sehingga gigitan pada manusia terjadi perpindahan virus yang sudah mengalami replikasi di tubuh nyamuk ke manusia melalui air liurnya, sehingga menyebabkan penyakit DBD. Oleh sebab itu, peningkatan curah hujan diikuti oleh peningkatan AHJ, sehingga jumlah kasus DBD di masyarakat meningkat.

Curah hujan tidak secara langsung berpengaruh terhadap $\mathrm{AHJ}$, tetapi secara tidak langsung melalui siklus kehidupan vektor (Gambar 3). Faktor yang langsung berhubungan dengan $\mathrm{AHJ}$ adalah suhu dan kelembaban udara karena berpengaruh terhadap aktivitas dan metabolisme nyamuk. Nilai koefisien determinasi hubungan curah hujan dan $\mathrm{AHJ}$ adalah 0,286 yang menunjukkan hanya $28,6 \%$ variasi proporsi $\mathrm{AHJ}$ yang dapat dijelaskan oleh curah hujan. Sisanya sebanyak $71,4 \%$ dijelaskan oleh faktor lain, seperti aktivitas nyamuk, metabolisme nyamuk, suhu udara, kelembaban udara, keaktivan individu manusia, pengetahuan, sikap dan perilaku masyarakat, vegetasi, kerapatan bangunan, topografi, infrastruktur atau lainnya yang menjadi keterbatasan penelitian. Hal tersebut kemungkinan besar yang terjadi di Jakarta Timur, sebab sepanjang tahun 2004 tercatat 6991 kasus merupakan yang tertinggi di antara lima wilayah DKI lainnya (Tabel 3 dan Gambar 1). Di Jakarta Timur, vegetasi ditemukan relatif lebih banyak daripada lima wilayah DKI yang lain. Dengan demikian, selain Ae. Aegypti, Ae. albopictus yang lebih menyukai habitat di kebun juga diduga sebagai sumber penular. Keadaan wilayah pemukiman yang padat dengan kelas sosial yang rendah menyebabkan penularan lebih cepat terjadi karena jarak terbang nyamuk Aedes hanya sekitar 50-100 m. Pada penelitian yang dilakukan di perkampungan padat di Taiwan, diketahui bahwa satu nyamuk Aedes betina hanya mengunjungi satu atau dua rumah dan hanya $0,7 \%$ yang mengunjungi lima rumah. ${ }^{10}$ Jika pemukiman padat dengan banyak vegetasi, maka Ae. albopictus pun dapat menjadi penular dengan AHJ tinggi di Jakarta Timur $(1,42)$ (Tabel 1).

Model dinamika sistem yang dibangun menunjukkan empat subsistem yang yang saling terkait yang mempengaruhi kejadian kasus DBD. Subsistem pertama adalah iklim yang mencakup berbagai faktor cuaca yang mempengaruhi kehidupan vektor meliputi curah hujan, suhu, kelembaban, dan $\mathrm{CO}_{2}$ yang berperan memberi dampak efek rumah kaca di lingkungan urban. Subsistem kedua adalah siklus kehidupan nyamuk Aedes, mulai telur sampai nyamuk dewasa yang ditunjukkan dengan tanda panah positif yang berarti bahwa semakin banyak telur semakin banyak nyamuk dewasa. Faktor penghubung subsistem iklim dan subsistem nyamuk adalah tempat perindukan nyamuk (TPN) atau breeding place. TPN yang sangat terpengaruh oleh curah hujan. Ketika curah hujan tinggi maka TPN cepat terisi dan hubungan ini ditunjukkan dengan tanda panah positif yang berarti hu- 
bungan yang saling memperkuat. ${ }^{11}$

Faktor penghubung subsistem iklim yang lain adalah suhu lingkungan yang berengaruh terhadap masa inkubasi ekstrinsik (PIE) nyamuk. PIE dipengaruhi oleh suhu lingkungan, kelembaban, tingkat viremia pada manusia, dan galur virus. ${ }^{10}$ Peningkatan suhu akan mempersingkat PIE dan meningkatkan transmisi. Suhu yang meningkat sampai $34^{\circ} \mathrm{C}$ akan mempengaruhi suhu air pada TPN yang selanjutnya berpengaruh terhadap penetasan telur menjadi larva secara lebih cepat. ${ }^{8}$ Subsistem vektor dan subsistem penyakit dihubungkan oleh faktor AHJ dan peran virus dengue. Keberadaan penyakit DBD ditentukan oleh kejadian kontak antara nyamuk dengan manusia. Hal tersebut terjadi dengan asumsi semakin tinggi populasi nyamuk semakin meningkat nilai AHJ, sehingga panah penghubung menjadi positif. Populasi nyamuk Aedes yang semakin tinggi akan diikuti oleh peningkatan populasi Aedes infektif yang membawa virus dengue. Hubungan ini ditunjukkan oleh panah bertanda positif.

Setelah nyamuk Aedes menggigit manusia, virus bereplikasi di dalam tubuh manusia. Semakin banyak virus terinkubasi ke manusia, semakin banyak manusia menjadi penular sehingga kasus DBD di masyarakat semakin banyak. Mata rantai ini digambarkan dengan panah positif. Pada Gambar 3, infrastruktur juga dimasukkan sebagai salah satu faktor yang mempengaruhi peningkatan morbiditas, dan peningkatan risiko sakit pada masyarakat, sehingga tanda panah yang digunakan adalah positif. Variabel aktivitas manusia diindikasikan dengan tingkat pemakaian bahan bakar minyak dalam kehidupan masyarakat sehari-hari. Dampak dari penggunaan bahan bakar ini berupa emisi $\mathrm{CO}_{2}$ yang berpengaruh pada pemanasan lingkungan pada area urban, ${ }^{12}$ sehingga hubungan variabel-variabelnya digambarkan dengan tanda panah positif. Faktor AHJ juga berhubungan dengan subsistem manusia melalui faktor keaktivan individu. Seseorang yang lebih banyak diam, semakin mudah didatangi nyamuk, terutama pada saat puncak gigitan Aedes, semakin tinggi AHJ. Sehingga hubungan ini digambarkan dengan panah bertanda negatif.

Simulasi hasil pengembangan model dasar yang dibangun selama dua tahun (Gambar 4) menunjukkan lonjakan kasus terjadi pada tahun 2004 (garis terputus). Grafik garis utuh menunjukkan angka kumulatif kasus DBD selama simulasi dua tahun yang memperlihatkan kecenderungan yang meningkat. Prediksi ini menunjukkan pada tahun-tahun mendatang kecenderungan kasus DBD akan terus meningkat. ${ }^{13} \mathrm{Hal}$ ini berarti bahwa jika masyarakat tidak melakukan pengendalian terpadu maka kasus DBD akan terus ada dan meningkat dari tahun ke tahun. Sebab secara alami, keadaan lingkungan global akan terus mendorong peningkatan kecepatan perkembangbiakan nyamuk dan virus. Dengan demikian, penu- laran DBD terjadi dan cepat semakin meluas ke wilayah yang pada awalnya tidak diperkirakan menjadi daerah endemis.

\section{Kesimpulan}

Kasus DBD mulai naik pada bulan Januari dan mencapai puncak pada bulan Februari-Maret. Bulan April mulai turun, September-November kasus mencapai minimum. Namun, pada bulan September saat curah hujan rendah justru AHJ meningkat tetapi kasus DBD rendah. Kasus DBD tertinggi terjadi di Jakarta Timur, secara berurutan diikuti Jakarta Selatan, Jakarta Barat, Jakarta Utara dan Jakarta Pusat. Curah hujan dan AHJ bersamasama mempengaruhi jumlah kasus DBD secara bermakna. Melalui sistem dinamik diketahui curah hujan tidak secara langsung mempengaruhi $\mathrm{AHJ}$ melainkan melalui siklus kehidupan vektor. Terdapat empat subsistem yang saling terkait dalam mempengaruhi terjadinya kasus DBD, yaitu subsistem iklim, subsistem vektor, subsistem manusia dan subsistem penyakit DBD. Melalui simulasi sistem dinamik diketahui jika tidak dilakukan pengendalian terpadu dan konsisten maka kasus DBD akan terus meningkat dari tahun ke tahun.

\section{Saran}

Simulasi dalam penelitian ini telah menghasilkan permodelan yang dapat digunakan untuk penyakit menular lainnya, karena melalui permodelan dinamika sistem dapat diketahui secara rinci model transmisi penyakit sehingga dapat ditentukan intervensi yang paling efektif dalam penanganan kasus penyakit menular tersebut. Menambah peran Juru Pemantau Jentik (Jumantik) sehingga dapat menjadi motivator masyarakat agar secara mandiri dan sukarela melakukan PSN dan peningkatan PSP mengenai penyakit demam berdarah dengue, termasuk mengenali gejala awal agar tidak terlambat mengambil keputusan berobat.

\section{Daftar Pustaka}

1. McMichael, A.J.; Haines, A.; Slooff,R.; Kovats, S., "Climate Change And Human Health, an Assessment Prepared by a Task Group on Behalf World Health Organization, the World Meteorological Organization and the United Nations Environment Programme”, World Health Organization, Geneva, 1996.

2. Gubler, Duane J.; Nalim, S.; Tan, R.; Saipan, H.; Saroso, J.S., "Variation in Susceptibility to Oral Infection With Dengue Viruses Among Geographics Strain of Aedes aegypti”, U.S. Naval Medical Research Unit no 2, Jakarta Detachment, and National Institute of Health Research and Development, Ministry of Health, Jakarta, am.J.Trop.Med.Hyg., 28(6), 1979.

3. World Health Organization, "Report on Insect Vectors and Human Health, Scientific Working Group”, Geneva, Switzerland, 2002.

4. Burke, Donald; Carmichael, Ann; Focks, Dana, Grimes, Darrell Jay, "Under The Weather, Climate, Ecosystem, and Infectious Disease", 
National Research Council, National Academic Press, Washington, D.C., 2001.

5. Bohra, Alpana; Andrianasolo, Haja, "Application of GIS in Modelling of Dengue Risk based on Socio-Cultural Data: Case of Jalor, Rajasthan, India”, Paper presented at the $22^{\text {nd }}$ Asian Conference on Remote Sensing, 5-9 November 2001, Centre for Remote Imaging, Sensing and Processing (CRISP), National University of Singapore, 2001,

6. Rothman, K.J.; Greenland, S., "Modern Epidemiology", $2^{\text {nd }}$ ed, Lippincort-Raven, 1998.

7. Jennings, G.B.; Bangs, M.; Tan, R.; Sie, A.; Suharyono, W.; Katarina, L.; Kustiman, T.; Masyhur, M., "Interepidemic Surveillance of Dengue Virus in Jakarta, 1989 - 1990”, International Symposium on Dengue and Dengue Hemorrhagic Fever, WHO - Mahidol University, Ministry of Public Health, Bangkok, Thailand, 1990.

8. Christophers, S. Rickard, 'Aedes aegypti (L.), The Yellow Fever Mosquito, its life history, bionomics and structure", Cambridge at The University Press, 1960.
9. Chungue, Eliane; Laille, Manola; Lepiniec, Loic; Deubel, Vincent; Roux, Jean, "Dengue and Dengue Hemorrhagic Fever in French Polynesia and new Caledonia: Molecular Studies of Dengue 1 and Dengue 3 Virus Strain”, International Symposium on Dengue and Dengue Hemorrhagic Fever, WHO-Mahidol University, Ministry of Public Health, Bangkok, Thailand, 1990.

10. Gubler, Duane J.; Kuno, G., "Dengue and Dengue Hemorrhagic Fever", CABI Publishing, 10 E 40 ${ }^{\text {th }}$ Street Suite 3203 NY 10016, USA, 2001.

11. Muhammadi; Aminullah, E.; Soesilo, B., "Analisis Sistem Dinamis, Lingkungan Hidup, Sosial, Ekonomi, Manajemen”, UMJ Press, Jakarta, 2001.

12. Miller, G. Tyler, "Living in The Environment, an Introduction to Environmental Science, Fourth Edition”, Wadsworth Publishing Company, Belmont, California A Division of Wadsworth, Inc, 1985.

13. Suroso, Thomas, "Strategi Baru Penanggulangan Demam Berdarah Dengue di Indonesia”, Kongres Nasional Jaringan Epidemiologi Nasional, Malang, 2003. 